\title{
ECONOMIC GROWTH: A SHORT HISTORY OF A CONTROVERSIAL IDEA
}

\author{
Gareth DALE ${ }^{1}$
}

\begin{abstract}
This paper explores the origins and evolution of the 'growth paradigm'--the idea that economic growth is natural, imperative, continuous, a fundamental social good, and the solution to manifold social ills. In pre-modern civilisations, it finds, the growth paradigm is absent. The paper proposes that, in close connection with the rise of capitalism and Europe's colonial land grab, a set of socio-economic, cultural and ideological changes conducive to the growth paradigm arose during the middle of the last millennium. The paper notes that a key moment in the advent of the growth paradigm was the seventeenth-century, with its mercantilist economists and its colonial missions. In the penultimate section of the paper, the ideology of growth in the nineteenth and twentieth centuries are traced. The concluding section unpacks the construction of the growth paradigm and explores its relationship to capitalism.
\end{abstract}

Keywords: Economic growth, GDP, growth paradigm, William Petty, capitalism.

JEL Code: B00, O.

\section{Introduction}

The politics of economic growth are complex and contested as never before. In rich countries, rates of GDP growth have declined, decade after decade since the 1960s. The 2008 crash was deep, and the post-crisis recovery has been slow. This poses problems for governments, given that their 'performance legitimacy' requires some degree of popular approval of their perceived success in charting a growth path that satisfies the citizenry's demand for goods and services. Where growth is low and governments choose to respond with austerity programmes, these bring additional misery and hardship - including tens of thousands of premature deaths in Britain alone.

In the same decades, growth scepticism has thrived. It takes two main forms: one highlights the impact of infinite growth on finite resources and on the natural environment. Recognition of the dangers of climate breakdown has transformed this debate - while mainstream opinion retains the traditional faith in growth, now refashioned as 'green growth', the heretics are rallying to 'degrowth'.

The other emphasises the disconnect between growth and social well-being. The days are long gone when growth was seen as the fast track to general prosperity, as normal and natural as sunrise. It is well established that the relationship between growth and well-being is partial at best. Such a correlation does exist, but weakens after a certain point - roughly speaking when per capita GDP exceeds $\$ 15,000$. At higher levels, the translation of growth into improvements in health and well-being is tenuous. Other variables, notably levels of equality, are critical.

\footnotetext{
1 Gareth Dale, Brunel University, gareth.dale@brunel.ac.uk
} 
In combination, these developments have motivated the 'Beyond GDP' agenda. Whether for reasons of growth scepticism or out of concern that if GDP growth remains slack governments' performance legitimacy will suffer too, political leaders, civil servants and academics - among them Nicolas Sarkozy, Jacinda Ardern, Gus O'Donnell, Joseph Stiglitz and Amartya Sen - are promoting alternative yardsticks.

To assess these debates it helps to dig into the history and morphology of the 'growth paradigm' - the belief that economic growth is good, imperative, essentially limitless, and the principal remedy for a litany of social problems - and ask the following: when and how did this paradigm originate?

\section{From Rain Dance to Nasdaq}

One response was offered in 1960 by Elias Canetti. In quasi-Nietzschean vein, he invoked a transhistorical 'will to grow'. Humans are always striving for more. Whether the parent monitoring her child's weight or the state official seeking to augment her power, or the community expanding its population, we all want growth. The desire to accumulate goods, the drive for economic growth, the wish for prosperity - they are all innate to human social being. Humans in groups are driven to seek increase: of their numbers, of the conditions of production, and of the products they require and desire. The very earliest homo sapiens sought the enlargement of their "own horde through a plentiful supply of children." ${ }^{2}$ And later, in the age of modern industrial production, the growth drive came into its own.

"If there is now one faith, it is faith in production, the modern frenzy of increase; and all the peoples of the world are succumbing to it one after the other. ... Every factory is a unit serving the same cult. What is new is the acceleration of the process. What in former days was generation and increase of expectancy, directed towards rain or corn, ... has today become production itself." ${ }^{3}$ A straight line runs from the rain dance to the Nasdaq.

But this is to confuse the wiring of our current economy with the wiring of the human brain. Canetti's 'will to grow' doesn't withstand scrutiny. The diverse behaviours he describes can't be reduced to a single logic. The 'will' behind creating babies is quite unlike the will to accumulate acreage or gold. And the latter is relatively recent. For much of the human story, societies were nomadic or semi-nomadic, and organised in immediate-return systems. Stashes of food were set aside to tide the group over for days or weeks, but long-term storage was impractical. The accumulation of possessions would hamper mobility. The measures that such societies used to reduce the risks of scarcity centred not on accumulating stores of goods but on knowledge of the environment, and interpersonal relationships (borrowing, sharing, and so on). The moral economy of sharing necessitates a muscular egalitarianism that is undermined by the accumulation of property.

Logics of accumulation - and, in the loosest sense, growth - were not initiated until the Neolithic revolution. Its technological and institutional transformations included settled agriculture and storage, class division, states, warfare and territoriality, and, later, the invention of money. Population growth joined with class exploitation and interstate competition to expand the sway of agrarian empires. Farmers enlarged the ploughlands, scholars penned proposals for improving

\footnotetext{
2 Elias Canetti (1984 [1960]) Crowds and Power, Peregrine, p. 108.

3 Elias Canetti (1984 [1960]) Crowds and Power, Peregrine, pp. 465, 192.
} 
the organisation of agriculture or trade, merchants amassed wealth, and rulers, seeking to enlarge population and tribute, extended their domains. Only now - in the post-Neolithic age - did gold achieve its fetish quality as the source and symbol of power.

Scour the documents from ancient civilisations and you'll find tales of competition for territory and the accumulation of property, but nothing that resembles the modern growth paradigm. No conception of 'an economy' that can grow, still less of one that tends to the infinite. And you'll find little, if any, notion of linear historical progress. Instead, cyclical cosmologies prevailed. A partial exception is the fourteenth century polymath, Ibn Khaldun. He developed a sophisticated analysis of growth dynamics. But his ideas were not widely adopted, and his theory is cyclical: it describes negative feedback mechanisms that ensure any economic upticks will necessarily hit barriers and retreat.

When, then, did the modern growth paradigm originate - and why?

\section{Petty's Arithmetic}

The evolution of the growth paradigm was integrally connected to the capitalist system and its colonial thrusts. The basic link between the growth drive and capitalism is transparent. The latter is a system of competitive accumulation. The former, in suggesting that the system is natural and brings benefit also to the ' $99 \%$ ', provides ideological cover in that growth serves as an idealised and democratised redescription of capital accumulation. But there's more to it than that. The capitalist transition was to a system of generalised commodity production, in which formal 'productive' economic activity takes the shape of commodities interacting through the price mechanism, in a regularised manner. If earlier political-economic thought had construed its subject as the affairs of the royal household, during the capitalist transition a new model emerged, with an interconnected market field posited as essentially outside the state.

In seventeenth-century England, just as the universe was being re-imagined by Newton et al as a machine determined by lawful regularities, the idea that economic behaviour follows natural laws became commonplace. By the close of the following century, Richard Cantillon had presented the market system as self-equilibrating, a machine that functions in a law-like manner; Quesnay's Tableau had depicted the economic system as a unified process of reproduction; Adam Smith had theorised the dynamics of economic growth; and philosophers (such as William Paley) had developed the creed that steady economic growth legitimates the social system and renders system-critical demands unnecessary and dangerous.

The same centuries experienced a revolution in statistics. In the England of 1600, the growth paradigm could scarcely have existed. No one knew the nation's income, or even its territory or population. By 1700 all these had been calculated, at least in some rough measure, and as new data arrived England's 'material progress' could be charted. Simultaneously, the usage of 'growth' had extended from the natural and concrete toward abstract phenomena: the growth of England's colonies in Virginia and Barbados, the 'growth of trade,' and suchlike.

But the capitalist transition revolutionised much more than the formal economy and economic concepts. As land came to be regarded as a commodity-like object, the idea - found to some degree in antiquity - that nature exists to serve the purposes of landowners and is fundamentally external to human beings, gained definition. The early-modern regimes of abstract social 
labour and abstract social nature (i.e. the constitution of labour and nature as commodities) were sustained by the scientific revolution, and also by the construction of capitalist time. Over centuries, time became flattened into an abstract, infinite and divisible continuum, one that permitted economic life to be re-imagined as subject to continuous growth and cultivation. Morality was upended, too, most significantly in the discarding of the age-old proscriptions against acquisitiveness.

The more that economic activity came to be marshalled behind the imperatives of capital accumulation, the more it became subject to regimes of 'improvement' and quantification. In Jacobean and Cromwellian England, these practices and discourses proliferated. Agrariancapitalist improvement was fuelled by scientific discoveries. These, in turn, were spurred on by the navigational and martial demands of explorers, freebooters and conquerors. European settlers in the New World not only exterminated and subjugated 'new' peoples, but turned to objectifying and cataloguing them, drawing comparisons with their own kind and 'improving' them. 'Improvement' and its theologically-intoxicated transplantation to colonial locations generated new data and new demands for detailed knowledge. How profitable is this tract of land, and its denizens? How can they be made more profitable? Answering such questions was enabled by modern accounting techniques, with their sharper definition of such abstractions as profit and capital.

No surprise, then, that the first statistically rigorous accounting of the wealth of a country (as distinct from, say, a royal household) was conducted by a capitalist on a colonial mission. William Petty planted quantification at the heart of scientific economics, crafted to the purposes of English merchants and empire, and gaining ideological force from the sheen of objectivity with which economic statistics - or 'political arithmetic' as he termed it - comes coated. In his work the conquest of nature and the idea of nature as a machine, and of the economy as a productive engine, blended to produce a new concept of wealth as resources and the productive power to harness them in contrast to the mercantilist concept, centred on the accumulation of bullion.

Colonisation of the New World contributed powerfully to capital accumulation in Western Europe, but it also spurred Europe's philosophers to elaborate a racialised progress ideology. The question of what to make of the peoples encountered in the Americas, and what implications followed from their property arrangements, stimulated a new reading of the human story: a narrative of social progress. From the vantage point of the colonialists, if 'they' were at the primitive stage, had 'we' once occupied it too?

Centred on a mythical ladder that climbs up from barbarism to civilisation, the progress idea hammered the diversity of human populations into a single temporal-economic chain. By indexing the richer and higher-tech nations (and 'races') as history's vanguard, it justified their bossing of the rest. It was a manifesto that drummed out capital's rhythms, and later found new forms as 'modernisation theory,' 'the development project,' and so forth, articulated through a grammar of 'growth.' Through its marriage to progress and development, in the belief that social advance requires a steady upward ratchet in national income, growth gained its ideological heft.

\section{The Globalisation of an Ideology}

In the nineteenth and twentieth centuries, the consolidation and globalisation of capitalist relations was accompanied by the growth paradigm. The first half of the twentieth century saw its definition sharpen. A pronounced shift occurred from a rather vague sense - long prevalent - 
that government should preside over economic 'improvement' and 'material progress' to an urgent conviction that promoting growth is a matter of national priority. Factors behind the shift included intensified geopolitical rivalry, and the increasing 'muscularity' of states, with their expanded bureaucratic apparatuses, surveillance systems and welfare provision, as well as the segue from the age of empires to that of nation states, a shift that helped consolidate the discourse of the 'national economy.' In many countries the expansion of suffrage was an additional factor: rights were extended and an infrastructure and ideology of national belonging was constructed with the aim of incorporating the lower orders as citizens into the body politic. With the Great Depression, restoring growth became an urgent project of states, and provided the context for the national income accounting that eventually led to GDP.

The acme of the growth paradigm was reached in the mid twentieth century. Growth was firmly established everywhere: in the state-capitalist economies of the 'Second World,' the market economies of the West, and the postcolonial world too. It became part of the economic-cultural furniture, and played a decisive part in binding 'civil society' into capitalist hegemonic structures - with social democratic parties and trade unions crucial binding agents. It came to be seen as the key metric of national progress and as a magic wand to achieve all sorts of goals: to abolish the danger of returning to depression, to sweeten class antagonisms, to reduce the gap between 'developed' and 'developing' countries, to carve a path to international recognition, and so on. There was a military angle too. For the Cold War rivals, growth promised geopolitical success. "If we lack a first-rate growing economy," cautioned JFK on the campaign trail, "we cannot maintain a first-rate defense." ${ }^{4}$ The greater the rate of growth, it was universally supposed, the lesser the economic, social and political challenges, and the more secure the regime.

The growth paradigm, I suggest, is a form of fetishistic consciousness. It functions as commodity fetishism at one remove. Growth, although the result of social relations among people, assumes the veneer of objective necessity. The growth paradigm elides the exploitative process of accumulation, portraying it instead as a process in the general interest. As Mike Kidron and Elana Gluckstein note, as a system of competition "capitalism depends on the growth of capital; as a class system it depends on obscuring the sources of that growth." ${ }^{5}$

For a long time, GDP growth was widely assumed to be the route to prosperity. Since then, cracks have appeared. In the rich world, we are beginning to realise that continuous GDP growth leads not simply to wealth and wellbeing, but to environmental collapse and barbecued grandchildren. But growth is not its own cause. GDP mirrors the power structure and form of value of capitalist society, but it doesn't define the system's core goal. That goal is the competitive accumulation of capital, and the accounting principles that guide it are those at the level of the firm, not the state. Put differently, the relentless increase in global resource throughput and environmental despoliation is not principally the result of states aspiring to a metric - higher GDP - but of industrial and financial firms, driven by market competition to expand turnover, develop new products, and increase profits and interest.

If the above analysis is correct, critical debates on growth should not focus solely on GDP while being coy about capitalism.

\footnotetext{
4 Quoted in Arndt, H. (1978) The Rise and Fall of Economic Growth. Harlow, Longman, p. 56.

5 Kidron, M. and Gluckstein, E. (1974), “Waste: US 1970”, in Kidron, M. Capitalism and Theory, London, Pluto.
} 


\section{References}

Arndt, H. (1978). The Rise and Fall of Economic Growth. Harlow, Longman.

Canetti, E., (1984 [1960]). Crowds and Power, Peregrine.

Kidron, M. and Gluckstein, E. (1974). "Waste: US 1970", in Kidron, M. Capitalism and Theory, London, Pluto. 